\title{
Current research trends on arsenic toxicology
}

\author{
Hermann M. Bolt
}

Published online: 9 May 2013

(c) Springer-Verlag Berlin Heidelberg 2013

Arsenic, a compound with a long history as a toxicant (Bolt 2012, 2013), continues to be a major public health issue in a number of countries worldwide (Golka et al. 2010; Martinez et al. 2011). As far as exposure is concerned, the most important matter of current publications is drinking water pollution (Maity et al. 2012; Deb et al. 2012; Guha Mazumder et al. 2012; Marchiset-Ferlay et al. 2012; Chen et al. 2012; Kumasaka et al. 2013). Another contemporary issue coming into focus is environmental contamination from (former) mining activities (Coelho et al. 2012; Li et al. 2012; Chakraborti et al. 2012) and from waste deposits (Moreno-Santini et al. 2012).

Mechanistically, adverse health effects result from processes such as induction of oxidative stress, alterations of DNA methylation, histone modification, mRNA expression, and others (Martinez et al. 2011). There is an intensive further development at present, which is reflected in current publication activities, also affecting this journal.

Therefore, the present issue of Archives of Toxicology again presents some outstanding examples for different aspects of arsenic-induced toxicity mechanisms.

One focal point of research is metabolism of arsenic compounds (Bolt and Stewart 2010). A review by Watanabe and Hirano (2013) addresses the requirements for $\mathrm{As}^{3+}$ methylation and the role of glutathione in this process. The $\mathrm{As}^{3+}$ species is highly reactive with thiols in general (Chang et al. 2012). This reaction is competitive to the oxidation of $\mathrm{As}^{3+}-\mathrm{As}^{5+}$, the latter being less toxic than $\mathrm{As}^{3+}$. The As-glutathione conjugate stability is seen as an important factor in the overall toxicity of arsenicals.

H. M. Bolt $(\bowtie)$

Leibniz Research Centre for Working Environment and Human Factors (IfADo), Ardeystr. 67, 44579 Dortmund, Germany

e-mail: bolt@ifado.de
As stressed in a previous Editorial (Bolt 2012), combination effects between As and other toxicants are an upcoming research issue, mainly driven by practical environmental situations. Thus, in Bangladesh well water, combinations of $\mathrm{As}$ and $\mathrm{Fe}$ are found, and $\mathrm{Fe}$ may act synergistically on distinct signalling pathways, as now shown by Kumasaka et al. (2013). The authors demonstrate that this situation is improved by remediation of the water using a low-cost and high-performance absorbent.

From the standpoint of mechanistic toxicology, a most important research focus related to arsenic is on carcinogenic pathways. Oxidative stress and apoptotic mechanisms appear to play a major role (Bolt and Hengstler 2011). Just recently this year, Sinha et al. (2013) presented a review collecting evidence that the cellular redox state and associated complications are closely associated with Nrf2 and its different molecular responses. In relation to As-mediated urothelial cancer, Liu et al. (2013) discuss the downstream effects on signalling pathways of oxidative stress. Specifically related to skin cancer, Jiang et al. (2013) point to the epithelial-mesenchymal transition (EMT) acquisition of cancer stem cell (CSC)-like properties as essential steps in the initiation of human skin cancers. They present arguments that EMT, with acquisition of a CSC-like phenotype mediated by IKK $\beta / \mathrm{I} \kappa \mathrm{K} \alpha /$ RelA signal pathway via Snail, contributes to As-induced skin carcinogenicity. In addition, Pastoret et al. (2013) discuss a role of As-induced downregulation of HNF1 $\alpha$ and HNF4 $\alpha$ in cancer development.

Apart from being a highly relevant environmental pollutant, As has a long history of medical use. Today, arsenic trioxide is a most effective drug for treatment of acute promyelocytic leukaemia (APL). Also, this aspect is covered in the present issue of Archives of Toxicology. Xu et al. (2013) point to the mechanism underlying HL-60 cell resistance to $\mathrm{As}^{3+}$ and point to the implication of the 
multidrug resistance protein MRP1. Yu et al. (2013) investigate the effect of the antioxidant resveratrol on $\mathrm{As}^{3+}$-induced nephrotoxicity and suggest that resveratrol may be used in post-remission therapy of APL after treatment with $\mathrm{As}^{3+}$, in order to prevent nephrotoxicity.

In total, the current issue of Archives of Toxicology again presents a number of highly topical and timely aspects of arsenic, which is a scientifically and practically important research field in toxicology.

\section{References}

Bolt HM (2012) Arsenic: an ancient toxicant of continuous public health impact, from Iceman Ötzi until now. Arch Toxicol 86(6):825-830

Bolt HM (2013) Current developments in toxicological research on arsenic. EXCLI J 12:64-74

Bolt HM, Hengstler JG (2011) Most cited articles: ethanol-induced hepatotoxicity, anticarcinogenic effects of polyphenolic compounds in tea, dose-response modeling, novel roles of epoxide hydrolases and arsenic-induced suicidal erythrocyte death. Arch Toxicol 85(12):1485-1489

Bolt HM, Stewart J (2010) Arsenic: metabolism and transport mechanisms in human hepatocytes. Arch Toxicol 84(1):1-2

Chakraborti D, Rahman MM, Murrill M, Das R, Siddayya Patil SG, Sarkar A HJD, Yendigeri S, Ahmed R, Das KK (2012) Environmental arsenic contamination and its health effects in a historic gold mining area of the Mangalur greenstone belt of Northeastern Karnataka, India. J Hazard Mater. doi:10.1016/j. jhazmat.2012.10.002. [Epub ahead of print]

Chang YY, Kuo TC, Hsu CH, Hou DR, Kao YH, Huang RN (2012) Characterization of the role of protein-cysteine residues in the binding with sodium arsenite. Arch Toxicol 86(6):911-922

Chen JW, Wang SL, Wang YH, Sun CW, Huang YL, Chen CJ, Li WF (2012) Arsenic methylation, GSTO1 polymorphisms, and metabolic syndrome in an arseniasis endemic area of Southwestern Taiwan. Chemosphere 88(4):432-438

Coelho PS, Costa S, Silva S, Water A, Ranville J, Sousa ACA, Costa C, Coelho M, García-Lestón J, Pastorinho, Laffon B, Pásaro E, Harrington C, Taylor A, Teixeira JP (2012) Metal(loid) levels in biological matrices from human populations exposed to mining contamination-Panasqueira Mine (Portugal). J Toxicol Environ Health, Part A 75(13-15):893-908

Deb D, Biswas A, Ghose A, Das A, Majumdar KK, Guha Mazumder DN (2012) Nutritional deficiency and arsenical manifestations: a perspective study in an arsenic-endemic region of West Bengal, India. Public Health Nutr 27:1-12. [Epub ahead of print]

Golka K, Hengstler JG, Marchan R, Bolt HM (2010) Severe arsenic poisoning: one of the largest man-made catastrophies. Arch Toxicol 84(8):583-584

Guha Mazumder D, Purkayastha I, Ghose A, Mistry G, Saha C, Nandy AK, Das A, Majumdar KK (2012) Hypertension in chronic arsenic exposure: a case control study in West Bengal.
J Environ Sci Health A Tox Hazard Subst Environ Eng 47(11): $1514-1520$

Jiang R, Li Y, Xu Y, Zhou Y, Pang Y, Shen L, Zhao Y, Zhang J, Zhou J, Wang X, Liu Q (2013) EMT and CSC-like properties mediated by the IKK $\beta / \mathrm{I} \kappa \mathrm{B} \alpha /$ RelA signal pathway via the transcriptional regulator, snail, are involved in the arsenite-induced neoplastic transformation of human keratinocytes. Arch Toxicol 87, this issue. [Epub ahead of print 2012 Oct 16]

Kumasaka MY, Yamanoshita O, Shimizu S, Ohnuma S, Furuta A, Yajima I, Nizam S, Khalequzzaman M, Shekhar HU, Nakajima T, Kato M (2013) Enhanced carcinogenicity by coexposure to arsenic and iron and a novel remediation system for the elements in well drinking water. Arch Toxicol 87(3):439-447

Li Y, Zhang X, Yang L, Li H (2012) Levels of Cd, Pb, As, Hg, and Se in hair of residents living in villages around Fenghuan Polymetallic Mine, Southwestern China. Bull Environ Contam Toxicol 89(1):125-128

Liu S, Wang F, Yan L, Zhang L, Song Y, Xi S, Jia J, Sun G (2013) Oxidative stress and MAPK involved into ATF2 expression in immortalized human urothelial cells treated by arsenic. Arch Toxicol 87 (this issue) [Epub ahead of print 2013 Apr 17]

Maity JP, Nath B, Kar S, Chen CY, Banerjee S, Jean JS, Liu MY, Centeno JA, Bhattacharya P, Chang CL, Santra SC (2012) Arsenic-induced health crisis in peri-urban Moyna and Ardebok villages, West Bengal, India: an exposure assessment study. Environ Geochem Health 34(5):563-574

Marchiset-Ferlay N, Savanovitch C, Sauvant-Rochat MP (2012) What is the best biomarker to assess arsenic exposure via drinking water? Environ Int 39(1):150-171

Martinez VD, Vucic EA, Becker-Santos DD, Gil L, Lam WL (2011) Arsenic exposure and the induction of human cancers. J Toxicol 2011:431287. doi: 10.1155/2011/431287

Moreno-Santini V, Mansilla-Rivera I, García-Rodríguez O, Rodríguez-Sierra CJ (2012) A pilot study determining hair arsenic and lead levels in residents of a community established on a former landfill in Puerto Rico. Bull Environ Contam Toxicol 89(3): $572-576$

Pastoret A, Marcos R, Sampayo-Reyes A, Saucedo-Cardenas O, Lozano-Garza GH, Hernandez A (2013) Inhibition of hepatocyte nuclear factor 1 and 4 alpha (HNF1 $\alpha$ and HNF4 $\alpha$ ) as a mechanism of arsenic carcinogenesis. Arch Toxicol 87, this issue. [Epub ahead of print 2012 Oct 5]

Sinha D, Biswas J, Bishayee A (2013) Nrf2-mediated redox signaling in arsenic carcinogenesis: a review. Arch Toxicol 87(2):383-396

Watanabe T, Hirano S (2013) Metabolism of arsenic and its toxicological relevance. Arch Toxicol 87, this issue. [Epub ahead of print 2012 Jul 19]

Xu S, Zhang YF, Carew MW, Hao WH, Loo JF, Naranmandura H, Chris Le X (2013) Multidrug resistance protein 1 (ABCC1) confers resistance to arsenic compounds in human myeloid leukemic HL-60 cells. Arch Toxicol 87, this issue. [Epub ahead of print 2012 Oct 9]

Yu M, Xue J, Li Y, Zhang W, Ma D, Liu L, Zhang Z (2013) Resveratrol protects against arsenic trioxide-induced nephrotoxicity by facilitating arsenic metabolism and decreasing oxidative stress. Arch Toxicol 87, this issue. [Epub ahead of print 2013 Mar 8] 